\title{
IMPLEMENTASI NILAI-NILAI KARAKTER DALAM KEGIATAN PALANG MERAH REMAJA DI SEKOLAH BINAAN PMI
}

\author{
Ascosenda Ika Rizqi, Marzuki \\ Program Studi Ilmu Pengetahuan Sosial (IPS), Universitas Negeri Yogyakarta \\ sendasslaifcams@gmail.com,marzukiwafi@yahoo.co.id
}

\begin{abstract}
Abstrak
Penelitian ini bertujuan: mengimplementasikan nilai karakter dalam kegiatan PMR tingkat wira di sekolah binaan PMI Kota Malang. Jenis penelitian deskriptif kualitiatif yang dilaksanakan bulan Februari sampai April 2013 di SMAN 5 Malang, SMA Frateran Malang, SMKN 2 Malang, dan MAN Malang I. Teknik pengambilan data terdiri atas: wawancara, dokumentasi, dan observasi. Hasil penelitian menunjukkan: Nilai Kemanusiaan keempat sekolah dengan melaksanakan kegiatan kemasyarakatan dan donor darah; Nilai Kesamaan MAN I dan SMKN 2 menerapkan jiwa corsa, SMAN 5 menghilangkan batas senioritas, dan SMA Frateran melaksanakan outing; Nilai Kenetralan MAN I tidak membela organisasi manapun, SMKN 2 dan SMAN 5 memberikan santunan kepada siapapun, dan SMA Frateran boleh mengikuti ekstrakurikuler lain; Nilai Kemandirian MAN I dan SMAN 5 mengurus administrasi secara mandiri, SMKN 2 menerapkan disiplin waktu, SMA Frateran mengumpulkan kas; Nilai Kesukarelaan keempat sekolah dengan memberikan pertolongan tanpa imbalan; Nilai Kesatuan keempat sekolah dengan mempererat silaturahmi dengan warga sekolah; Nilai Kesemestaan MAN I berupa penyuluhan kesehatan, SMKN 2 dan SMA Frateran PMR selalu hadir di kegiatan sekolah, SMAN 5 mengirimkan duta untuk kegiatan nasional dan Internasional.
\end{abstract}

Kata Kunci: nilai-nilai karakter, Palang Merah Remaja, Palang Merah Indonesia

\section{IMPLEMENTATION OF VALUES IN CHARACTER EVENTS YOUTH RED CROSS PMI TARGET SCHOOLS}

\author{
Ascosenda Ika Rizqi, Marzuki \\ Program Studi Ilmu Pengetahuan Sosial (IPS), Universitas Negeri Yogyakarta \\ sendasslaifcams@gmail.com,marzukiwafi@yahoo.co.id
}

\begin{abstract}
The aim of this study is to implement character values of wira level of Youth Red Cross in target schools of Malang City Indonesian Red Cross. It is a descriptive qualitative research. The research was done for februari until april 2013 in SMAN 5 Malang, SMA Frateran Malang, SMKN 2 Malang, and MAN Malang I as the objects. Researcher used observation, interview, and documentation techniques for collecting the data. Then the data was analysed by data reduction, data abstraction, and making conclusion. The result show that MAN I and SMAN 5 are doing routine practice, participate in Youth Red Cross invitations, hold social actions, and have a big support from their alumni, SMKN 2 is also doing routine practice; members of Youth Red Cross collaborate with members of School Health Unit and them as youth agents, and SMA Frateran applies multicultural system on every member of Youth Red Cross and holds an evaluation of activity every end of even semester. There are the seven values that applied in those schools: humanity is realized by social activity, impartiality is realized by applying corps'spirit, neutrality means helping without differentiate, independence means do not depend on school, voluntary service means giving service without desire for gains, unity is gotten by strengthen the bonds of friendship, and universality can be realized by participate on national and international events.
\end{abstract}

Keywords: Character Values, Youth red Cross, Indonesian Red Cross 


\section{Pendahuluan}

Kajian tentang pendidikan pada dasarnya tidak dapat dilepaskan dari kehidupan manusia dan lingkungan sekitarnya karena manusia hidup tumbuh dan berkembang didasarkan atas proses pendidikan dan lingkungan sosial yang membentuknya.

Menurut Saleh Marzuki (2009:135) pendidikan dipandang sebagai proses belajar sepanjang hayat manusia, artinya pendidikan merupakan upaya manusia untuk mengubah dirinya ataupun orang lain selama dia hidup. Pendidikan hendaknya lebih dari sekedar masalah akademik atau perolehan pengetahuan, kemampuan, dan mata pelajaran secara konvensional, melainkan harus mencakup berbagai kecakapan yang diperlukan untuk menjadi manusia yang lebih baik. Menurut Undang-Undang no. 20 tahun 2003 tentang Sistem Pendidikan Nasional pada Bab I Pasal 1 tertulis bahwa:

Pendidikan adalah usaha sadar dan terencana untuk mewujudkan suasana belajar dan proses pembelajaran agar peserta didik secara aktif mengembangkan potensi dirinya untuk memiliki kekuatan spiritual keagamaan, pengendalian diri, kepribadian, kecerdasan, akhlak mulia, serta keterampilan yang diperlukan dirinya, masyarakat, bangsa dan negara.

Menurut Hasibuan \& Mudjiono (2002:11) pendidikan terjadi dalam proses pergaulan anak dengan orang dewasa. Melalui komunikasi dan interaksi sosial yang diletakkan berdasarkan norma akan mempengaruhi jiwa dan intelegensia anak untuk tumbuh dan berkembang membentuk manusia yang bertanggung jawab.

Menurut Umar Tirtarahardja \& La Sulo (2005:37) bahwa tujuan pendidikan memuat gambaran tentang nilai-nilai yang baik, luhur, pantas, benar, dan indah dalam kehidupan. Karena itu, tujuan pendidikan memiliki dua fungsi yaitu: memberikan arah kepada segenap kegiatan dan merupakan sesuatu yang ingin dicapai oleh segenap kegiatan pendidikan. Umar Tirtarahardja \& La Sulo (2005:194) menuliskan beberapa aliran pendidikan yang kita kenal, antara lain: aliran empirisme yang dirintis John Locke dengan mengenalkan teori tabularasa, yaitu anak seperti kertas putih yang tumbuh dan berkembang didasarkan atas pengaruh faktor lingkungan yang sangat dominan.

Aliran Nativisme menurut Umar Tirtarahardja \& La Sulo (2005:196-198) yang dirintis oleh Schopenhauer dengan teori nativisme menyatakan bahwa tumbuh kembang anak ditentukan oleh pembawaannya. Sedangkan aliran konvergensi di tetapkan bahwa faktor lingkungan dan pembawaan sejak lahir yang mempengaruhi berkembangnya anak. Atas dasar pemahaman di atas, maka konsep pendidikan dikembangkan melalui mekanisme proses belajar mengajar yang disebut sekolah, dimana peran sekolah sebagai mata rantai perantara dan media pengembangan diri, intelegensi, imajinasi kreatif, dan pembentukan watak atau karakter dari anak didik.

Menurut Oong Komar (2006:5) sekolah memiliki beberapa fungsi dan peran sebagai berikut: Iklim sekolah bersifat demokratis dan tanpa diskriminatif; Semua siswa memiliki inisiatif, kreatif, dan berkebebasan yang bertanggung jawab secara etis; Penyusunan kurikulum dilakukan di sekolah sendiri dengan memperhatikan masalah yang berkembang disekitarnya; Isi pengajaran bertolak dari kepentingan siswa dan menitikberatkan kepada pemecahan masalah sendiri, kemandirian, dan persaingan yang sehat; Peran guru sebagai motivator yang menumbuhkan minat siswa

Bertolak dari peran dan fungsi sekolah tersebut, maka guru dalam berinteraksi dengan anak didik di sekolah sebaiknya menggunakan pendekatan bimbingan, pengajaran, dan latihan. Bimbingan mengantarkan intelegensi dan kecakapan, dengan pengajaran menurut Oong Komar (2006:3) adalah pemberian pengalaman yang berhubungan dengan iptek. Pengajaran menunjuk pada aspek kognitif, selain itu dapat membantu siswa untuk memperoleh pengetahuan dan kecerdasan dalam rangka transformasi budaya, sedangkan latihan adalah suatu proses pengulangan perbuatan untuk mencapai kemahiran. Latihan menunjuk pada aspek psikomotorik, selain itu juga membentuk skill (keterampilan) dan kebiasaan hidup lebih baik. Hal ini diperkuat oleh teori Saleh Marzuki (2009:172) yaitu pelatihan akan menghasilkan tindakan yang dapat diulang-ulang dan dapat mengakibatkan motivasi diri dan perbaikan yang lebih maju. 
Peran dan fungsi sekolah membentuk dan mempengaruhi proses tumbuh kembang anak yang dikelola melalui proses manajemen sekolah. Salah satu upaya mewujudkan manajemen sekolah adalah dengan melakukan kegiatan ekstrakurikuler. Kegiatan ekstrakurikuler sebaiknya tidak diposisikan sebagai suplemen semata atau disepelekan, melainkan menjadi bagian yang perlu diperhatikan sejajar dengan kegiatan belajar mengajar di kelas, karena ekstrakurikuler memberikan manfaat dan dampak terhadap perilaku serta pola pikir siswa, artinya pendidikan diluar kelas memiliki bobot yang sama dengan proses belajar mengajar dikelas. Oleh karena itu, baik siswa, orang tua, pihak sekolah, maupun masyarakat harus saling memberikan dukungan yang sinergis, lebih-lebih untuk mencapai prestasi yang maksimal.

Menurut Sungkowo, Direktorat Pembinaan SMA (2010:73) kegiatan pengembangan diri merupakan upaya pembentukan watak dan kepribadian peserta didik yang dilakukan melalui bimbingan konseling dan ekstrakurikuler. Kegiatan ekstrakurikuler merupakan wadah yang disediakan oleh satuan pendidikan untuk menyalurkan minat, bakat, hobi, kepribadian, dan kreativitas peserta didik yang dapat dijadikan sebagai alat untuk mendeteksi talenta peserta didik.

Tujuan kegiatan ekstrakurikuler yang tercantum dalam Permendiknas no. 39 tahun 2008 tentang pembinaan kesiswaan, adalah sebagai berikut: Mengembangkan potensi siswa secara optimal dan terpadu yang meliputi bakat, minat, dan kreativitas; Memantapkan kepribadian siswa untuk mewujudkan ketahanan sekolah sebagai lingkungan pendidikan sehingga terhindar dari usaha dan pengaruh negatif dan bertentangan dengan tujuan pendidikan; Mengaktualisasikan potensi siswa dalam pencapaian prestasi unggulan sesuai bakat dan minat; Menyiapkan siswa agar menjadi warga masyarakat yang berakhlak mulia, demokratis, menghormati hak-hak asasi manusia dalam rangka mewujudkan masyarakat madani (civil society).

Hal ini juga diperkuat dalam Keputusan Menteri Pendidikan Nasional RI Nomor 125/U/2002 tentang Kalender Pendidikan dan Jam Belajar Efektif di Sekolah, Bab V pasal 9 ayat 2, dinyatakan bahwa:
Pada tengah semester 1 dan 2 sekolah melakukan kegiatan olahraga dan seni (Porseni), karyawisata, lomba kreativitas atau praktik pembelajaran yang bertujuan untuk mengembangkan bakat, kepribadian, prestasi dan kreativitas siswa dalam rangka mengembangkan pendidikan anak seutuhnya.

Pada bagian Lampiran Keputusan Mendiknas Nomor 125/U/2002 tanggal 31 Juli 2002 disebutkan:

Liburan sekolah atau madrasah selama bulan Ramadhan diisi dan dimanfaatkan untuk melaksanakan berbagai kegiatan yang diarahkan pada peningkatan akhlak mulia, pemahaman, pendalaman dan amaliah agama termasuk kegiatan ekstrakurikuler lainnya yang bermuatan moral.

Pernyataan-pernyataan dalam Kepmendiknas tersebut menegaskan bahwa: (1) kegiatan ekstrakurikuler merupakan bagian yang tidak terpisahkan dari keseluruhan program pendidikan di sekolah; dan (2) pelaksanaan kegiatan ekstrakurikuler sebagai realisasi dari perencanaan pendidikan yang tercantum dalam kalender sekolah.

Dalam Standar Isi Permendiknas nomor 22 tahun 2006 antara lain diatur mengenai struktur kurikulum, bahwa KTSP terdiri atas beberapa komponen, di antaranya pengembangan diri. Berdasarkan Panduan Pengembangan KTSP yang diterbitkan oleh BSNP, antara lain dinyatakan:

Pengembangan diri bukan merupakan mata pelajaran yang harus diasuh oleh guru. Pengembangan diri bertujuan memberikan kesempatan kepada peserta didik untuk mengembangkan dan mengekspresikan diri sesuai dengan kebutuhan, bakat, dan minat setiap peserta didik sesuai dengan kondisi sekolah. Kegiatan pengembangan diri difasilitasi dan atau dibimbing oleh konselor, guru, atau tenaga kependidikan yang dapat dilakukan dalam bentuk kegiatan ekstrakurikuler.

Secara umum, kegiatan ekstrakurikuler yang dapat dikembangkan oleh sekolah setidaktidaknya mencakup kegiatan-kegiatan untuk memfasilitasi peserta didik mencapai butir-butir Standar Kompetensi Lulusan (SKL) sebagaimana 
dituangkan dalam Permendiknas nomor 23 tahun 2006.

Fakta di lapangan terdapat berbagai hambatan dalam pelaksanaan kegiatan ekstrakurikuler di sekolah, berdasarkan hasil pengamatan di lapangan baik yang terkait dengan ketersediaan sarana prasarana, sumber dana yang kurang, dan keterbatasan sumber daya manusia yang belum mampu merencanakan, melaksanakan, mengendalikan, dan mengembangkan kegiatan ekstrakurikuler menjadi satu kesatuan program belajar mengajar di sekolah. Faktor lain yang terkait sebagai kendala adalah peran dan kepedulian orang tua serta pihak masyarakat yang kurang memahami arti pentingnya kegiatan ekstrakurikuler, baik yang disebabkan kesibukan dan atau ketidakpahaman terhadap kegiatan ekstrakurikuler itu sendiri, sehingga program dan kegiatan ekstrakurikuler juga tidak berkembang.

Menurut Husaini Usman (1998:1) "Manusia adalah makhluk organisasi, oleh karena itu begitu lahir ke dunia ia otomatis menjadi anggota organisasi genetis yang disebut organisasi keluarga". Ini berarti, bahwa manusia tidak dapat lepas dari keberadaannya menjadi anggota dari suatu organisasi, baik sebagai anggota rukun tetangga, rukun warga, kelurahan, kecamatan, bahkan warga negara Indonesia dan anggota dunia. Kegiatan di sekolah, sejak taman kanakkanak sampai perguruan tinggi, ia menjadi anggota organisasi pendidikan, karena organisasi diciptakan untuk manusia bukan manusia untuk organisasi.

Pengembangan kegiatan ekstrakurikuler merupakan bagian dari pengembangan organisasi sekolah, berbeda dari pengaturan kegiatan intrakurikuler yang secara jelas disiapkan dalam perangkat kurikulum. Kegiatan ekstrakurikuler lebih mengandalkan inisiatif sekolah, namun dalam pelaksanaannya sangat mengharapkan guna menampung dan mengembangkan kreativitas siswa-siswinya sehingga secara bersama-sama dengan kegiatan kurikuler dapat meningkatkan kualitas hasil belajar. Keaktifan siswa menjadi prioritas utama sebagai pendukung kegiatan. Selain diperlukan program kegiatan ekstrakurikuler yang jelas, memilih pembina profesional harus diutamakan terutama yang mampu memotivasi semangat siswa untuk mengikuti program kegiatan ekstrakurikuler.
Metode pembinaan yang berkesinambungan dengan mendapatkan dukungan manajemen sekolah menjadi salah satu jalan dalam mendorong siswa untuk aktif dalam kegiatan ekstrakurikuler, di samping faktor sarana prasarana yang memadai dengan pengaturan jadwal yang tepat. Hal yang tidak kalah penting adalah dukungan orang tua untuk ikut memberikan bimbingan di luar sekolah atau lingkungan keluarga, dalam menanamkan motivasi dan dukungan moral agar aktif dan memberikan pemahaman bahwa kegiatan ekstrakurikuler bukan beban bagi siswa, melainkan menjadi kesatuan unit pembelajaran di sekolah secara menyeluruh.

Dukungan yang lain adalah melalui tokoh masyarakat yang diharapkan dapat berperan dengan baik, karena tokoh masyarakat dinilai memiliki kewibawaan, dan kemampuan, untuk melaksanakan kerjasama yang sangat diperlukan guna menimbulkan perlindungan serta rasa aman dan nyaman terhadap pelaksanaan kegiatan di sekolah. Berbagai macam kegiatan ekstrakurikuler, misalnya pramuka, PMR kegiatan tersebut akan menjadi semakin positif apabila mendapatkan dukungan dari pihak sekolah maupun masyarakat. Bentuk kegiatannya dilakukan dengan mengadakan latihan keterampilan, kedisiplinan militer yang melibatkan tokoh yang berkompeten dibidangnya.

Diharapkan kegiatan ekstrakurikuler di sekolah dapat berkembang dengan baik dan maksimal, oleh karena itu dalam hal ini harus ada kerjasama yang kuat dan peningkatan kesepahaman dari semua stakeholder yang ada. Pendanaan dan pelaksanaan evaluasi secara rutin terhadap kegiatan ekstrakurikuler sangat diperlukan untuk menyempurnakan perencanaan program dan pelaksanaan program. Kegiatan ekstrakurikuler yang baik dan terprogram diharapkan mampu menjadikan siswa untuk berperilaku baik dan mencerminkan nilai-nilai yang seharusnya dijunjung tinggi. Hal tersebut akan mengurangi perilaku menyimpang, karena waktu luangnya digunakan untuk kegiatan yang positif dan terpantau.

Kegiatan ekstrakurikuler diharapkan dapat memenuhi kebutuhan yang diminati siswa untuk memperoleh pengetahuan dan pengalaman terhadap berbagai mata pelajaran yang pada suatu saat nanti bermanfaat bagi siswa dalam kehidupan 
sehari-hari. Dalam kegiatan ekstrakurikuler dikembangkan juga pengalaman yang bersifat nyata yang dapat membawa siswa pada kesadaran atas pribadi, sesama lingkungan, dan Tuhan-Nya. Dengan kata lain bahwa kegiatan ekstrakurikuler dapat meningkatkan aspek kecerdasan sosial atau kompetensi sosialnya, serta membangun dan mengembangkan karakter remaja. Samsuri (2012:8) mengungkapkan bahwa:

Pendidikan karakter juga dapat dilaksanakan semata-mata sebagai bagian dari program ekstra-kurikuler. Misal, seperti kegiatan kepanduan, layanan masyarakat (community service), dan atau program civic voluntary dalam tindakan insindental seperti relawan kegiatan mitigasi bencana.

Penulisan tesis ini lebih mengedepankan pelaksanaan nilai-nilai karakter yang difokuskan dalam nilai-nilai karakter remaja yang terangkum melalui Prinsip Dasar Gerakan Palang Merah Dan Bulan Sabit Merah Internasional. Adapun sasaran dari yang ingin diteliti adalah remaja usia pelajar yang tergabung dalam organisasi Palang Merah Remaja (PMR) tingkat wira atau setingkat SMA/SMK/MA yang mana sekolah tersebut termasuk dalam radar pantauan Palang Merah Indonesia (PMI) Kota Malang. Pilihan kegiatan Palang Merah Remaja (PMR) didasarkan pada tiga hal yaitu: Kegiatan siswa yang pengembangannya dilaksanakan secara bersama-sama dengan Palang Merah Indonesia (PMI) sebagai induk organisasi; Adanya kebutuhan dan keinginan sekolah untuk membentuk organisasi tersebut, karena orientasi programnya lebih kental dengan penanaman nilai-nilai dan watak kepribadian bangsa.

Adanya prinsip dasar gerakan palang merah dan bulan sabit merah internasional yang dijadikan sebagai dasar penanaman karakter, yaitu: kemanusiaan, kesamaan, kenetralan, kemandirian, kesukarelaan, kesatuan, dan kesemestaan yang dapat diuraikan sebagai berikut: Kemanusiaan (Humanity), adalah nilai dasar yang dimiliki oleh manusia, saling menolong dan saling membantu orang lain yang membutuhkan pertolongan. Secara internasional nilai kemanusiaan ini menjadikan dasar terbentuknya perdamaian dunia; Kesamaan (Impartiality), adalah upaya untuk menghilangkan perbedaan kebangsaan, kesukuan, agama, dan pandangan politik; Kenetralan (Neutrality), adalah tindakan tidak memihak atau melibatkan diri dalam pertentangan politik, kesukuan, agama, atau ideologi; Kemandirian (Independence), yaitu upaya mengedepankan inovasi dan integritas pelaksanaan kegiatan tanpa ada pengaruh atau ketergantungan pada pihak atau lembaga lainnya; Kesukarelaan (Voluntary Service), ialah tindakan pemberian pelayanan dan kerjasama secara sukarela tanpa didasari keinginan untuk mencari keuntungan apapun; Kesatuan (Unity), merupakan nilai penyatuan keanekaragaman objek penanganan yang dilakukan oleh satu perhimpunan dalam satu negara; Kesemestaan (Universality), merupakan nilai penyelarasan hak dan tanggung jawab terhadap sesama dalam melaksanakan tugas.

Hal tersebut juga diperkuat oleh ketua bidang penguatan sumber daya PMR dan relawan, Ulla Nuchrawaty Usman (2007:1) yang mengatakan bahwa:

Palang Merah Remaja adalah wadah pembinaan dan pengembangan anggota remaja Palang Merah Indonesia (PMI), yang selanjutnya disebut PMR. Palang Merah Indonesia (PMI) kota diseluruh Indonesia, dengan anggota lebih dari 3 juta orang, anggota Palang Merah Remaja (PMR) merupakan salah satu kekuatan PMI dalam melaksanakan kegiatan-kegiatan kemanusiaan dibidang kesehatan dan siaga bencana, mempromosikan prinsip-prinsip dasar gerakan palang merah dan bulan sabit merah internasional, serta mengembangkan kapasitas organisasi PMI.

Di Kota Malang dari data BPS 2011/2012 terdapat 100 lembaga pendidikan tingkat atas, empat lembaga di antaranya memiliki kegiatan PMR yang di asuh oleh Palang Merah Indonesia (PMI). Pembinaan PMR yang dilakukan oleh PMI ada di lembaga pendidikan memiliki jenjang mulai dari tingkat mula atau setingkat $\mathrm{SD} /$ MI, tingkat madya atau setingkat SMP/MTs, dan tingkat wira setingkat SMA/SMK/MA. Di kota Malang pembinaan PMR setingkat wira yang dibina oleh PMI pada 4 lembaga yaitu: SMA Negeri 5 Malang, SMA Katolik Frateran Malang, MAN 1 Malang, SMK Negeri 2 Malang. 
Kurun waktu 10 tahun terakhir sekolah tersebut memiliki prestasi akademik dan non-akademik terutama dalam bidang kepalang merahan yang membanggakan.

Kegiatan PMR pada umumnya mengacu pada pedoman PMI yang sudah ditetapkan, kemudian dalam pelaksanaannya di awasi bersama oleh pihak PMI kota setempat, pelatih, dan pengurus PMR sebagai pelaksana kegiatan. Semua kegiatan yang berkaitan dengan kepalangmerahan pada dasarnya mengacu pada Prinsip-Prinsip Dasar Palang Merah dan Bulan Sabit Merah Internasional serta Tri Bhakti Palang Merah, adapun kegiatan kepalangmerahan tersebut meliputi: kegiatan rutin PMR yang setiap minggunya selalu dilaksanakan di masing-masing sekolah atau unit, dan kegiatan insindental seperti donor darah, bakti sosial, bulan dana, peringatan hari besar palang merah, serta kegiatan perlombaan PMR baik tingkat Madya maupun Wira yang pelaksanaannya diselenggarakan oleh KSR-PMI unit Universitas yang ada di kota Malang.

Pelaksanaan kepalangmerahan di masingmasing sekolah di kota Malang selama 10 tahun terakhir memang mengalami peningkatan yang signifikan, terbukti bahwa kota Malang meraih banyak medali di perlombaan palang merah baik di tingkat propinsi maupun tingkat nasional, hal ini membuktikan bahwa pelaksanaan pembinaan PMR di kota Malang sejauh ini dapat dikatakan berhasil. Namun dalam pelaksanaan pembinaan PMR di setiap sekolah belum bisa dikatakan signifikan, karena aplikasi kegiatan Palang Merah disetiap sekolah berbeda-beda, sehingga menyebabkan kegiatan pembelajaran kepalangmerahan di setiap sekolah juga beragam dalam mengimplementasikan kegiatan PMR yang sudah di tetapkan oleh PMI kota Malang. Hal inilah yang menyebabkan aplikasi PrinsipPrinsip Dasar Palang Merah dan Bulan Sabit Merah Internasional juga mengalami hambatan, implikasinya adalah dalam setiap melaksanakan program kerja PMR dan lomba PMR baik tingkat kota maupun tingkat propinsi juga mengalami banyak hambatan.

Berdasarkan pemetaan dimaksud penelitian tesis, khususnya yang terkait dengan Palang Merah Remaja (PMR), maka tesis ini lebih difokuskan pada implementasi nilai-nilai karakter dalam kegiatan PMR tingkat wira binaan PMI kota Malang.

\section{Metode Penelitian}

Penelitian ini menggunakan jenis penelitian kualitiatif deskriptif. Tempat penelitian dilaksanakan di Sekolah Menengah Atas atau dalam istilah kepalangmerahan adalah tingkat wira di kota Malang yang memiliki kegiatan ekstrakurikuler Palang Merah Remaja (PMR). Di antara lembaga sekolah yang memiliki kegiatan ekstrakurikuler PMR adalah: SMA Negeri 5 Malang, SMK Negeri 2 Malang, MAN 1 Malang, SMA Katolik Frateran Malang. Waktu yang digunakan untuk melaksanakan penelitian adalah bulan Februari hingga April 2013 dan tidak menutup kemungkinan, apabila data masih kurang akan dilanjutkan penelitian lagi.

Subjek penelitian ini adalah anggota PMR aktif, Ketua PMR, dan Pelatih PMR di SMA Negeri 5 Malang, MAN Malang I, SMK Negeri 2 Malang, SMA Katolik Frateran Malang.

Objek dalam penelitian ini adalah Implementasi nilai-nilai karakter siswa dalam kegiatan PMR tingkat wira binaan PMI Kota Malang yang meliputi: Implementasi tiap-tiap prinsip Palang Merah dan Bulan Sabit Merah Internasional di masing-masing sekolah serta prinsip yang dominan digunakan di masing-masing sekolah.

Teknik observasi digunakan untuk mengumpulkan informasi data yang primer sesuai dengan kebutuhkan penelitian. Hal ini dilakukan untuk mengamati secara langsung di lapangan, bertemu dan berinteraksi dengan subjek penelitian. Teknik observasi yang digunakan peneliti dengan langsung terlibat dalam setiap kegiatan PMR di masing-masing sekolah.

\section{Hasil Penelitian dan Pembahasan}

Deskripsi kegiatan PMR di setiap sekolah adalah sebagai berikut:

\section{PMR MAN Malang I}

Palang Merah Remaja di MAN Malang I atau yang lebih di kenal dengan nama $D$ 'Crossnema. Sejak 10 tahun terakhir sekolah MAN Malang I bekerja sama dengan (Korps Sukarela) KSRPMI unit Universitas Negeri Malang (UM) sebagai pelatih. Pelatih dari KSR-PMI unit UM 
semuanya masih berstatus mahasiswa. Pada tahun 2009 salah satu pelatih yang sudah menyelesaikan kuliah di angkat menjadi PNS dan di tempatkan di MAN Malang I, sehingga pelatihnya diteruskan oleh mahasiswa lain yang masih menjadi aktivis KSR-PMI unit UM.

Kegiatan pelatihan rutin dilaksanakan setiap hari sabtu jam 13.00-15.30 WIB. Pesertanya adalah kelas X dan XI berjumlah 73 orang terdiri dari 7 siswa laki-laki sisanya siswa perempuan. Materi kegiatannya berdasarkan program kerja yang disusun oleh tim PMR sekolah yang meliputi: pertolongan pertama, perawatan keluarga, bongkar pasang tenda, siaga bencana, donor darah, dan kepemimpinan. Kegiatan donor darah dilakukan secara rutin setiap 3 bulan sekali dan kegiatan insindental berupa bakti sosial.

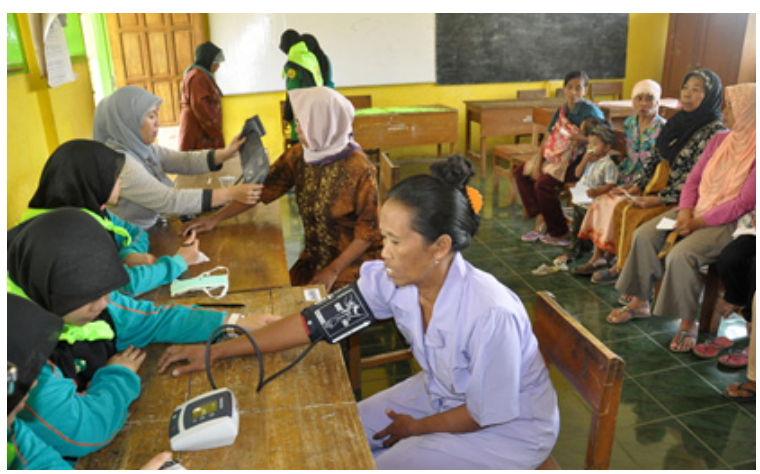

Gambar 1. kegiatan Bakti Sosial (BAKSOS) oleh anggota PMR MAN Malang I

Kegitan lain yang dilakukan adalah mengadakan lomba PMR bernama (Ajang Evaluasi Palang Merah) JAVAMERA untuk tingkat madya dengan peserta siswa setingkat SMP-MTs dimana siswa yang menjadi anggota PMR-PMI MAN Malang I bertugas sebagai panitia. Kegiatan ini diadakan setiap 2 tahun sekali se-wilayah Malang Raya (Kota Malang, Kabupatena Malang, Kota Batu).

Selain mengadakan lomba, PMR-PMI MAN Malang I sering mengikuti lomba yang diadakan oleh KSR-PMI unit yang ada di berbagai perguruan tinggi baik se-wilayah Malang Raya maupun se-wilayah Jawa Timur. Semua kegiatan PMR di bawah pengawasan PMI kota Malang dan PMR-PMI MAN Malang I sebagai satu-satunya sekolah yang sudah mendapatkan sertifikasi dari PMI kota Malang sehingga PMR di sekolah menjadi nama PMR-PMI unit MAN Malang I
MAN Malang I dalam mengimplementasikan nilai-nilai karakter adalah dengan mengadakan latihan rutin, adapun kegiatan latihan rutin yang dimaksud adalah pemberian materi pertolongan pertama yang diharapkan siswa mampu mengaplikasikan pertolongan saat dibutuhkan dan melatih siswa untuk memiliki rasa saling tolong menolong dan memiliki jiwa kemanusiaan yang tinggi.

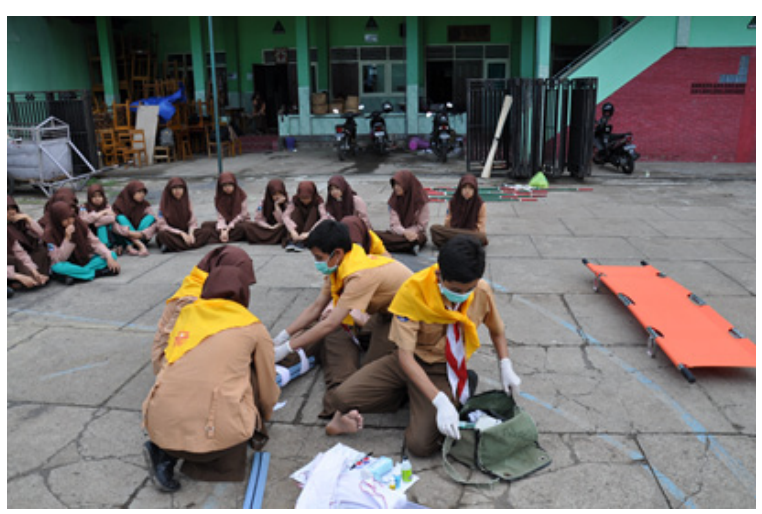

Gambar 2. Suasana latihan rutin PMR di MAN Malang I

\section{PMR SMA Katolik Frateran}

Kegiatan PMR yang dilaksanakan di SMA Katolik Frateran Malang disebut dengan FYRC (Frateran Youth Red Cross) sudah ada sejak pertengahan tahun 90an, tetapi tampak ada perkembangan pada awal semester tahun 2007. Kegiatan PMR dilaksanakan bekerja sama dengan PMI kota Malang dalam penyelenggaraan kegiatan latihan rutin. Selama pembinaan PMI kota Malang mengakomodasi tenaga pelatih dari berbagai unit Unit Kegiatan Mahasiswa (UKM) dari KSR-PMI unit Universitas Kanjuruhan Malang, KSR-PMI unit UM, dan KSR-PMI unit UIN Maulana Malik Ibrahim Malang.

Kegiatan PMR di SMA Katolik Frateran diikuti oleh kelas X dan XI berjumlah 34 siswa terdiri dari 12 laki-laki dan sisanya perempuan, kegiatan ini dilaksanakan setiap hari Sabtu mulai jam 11.30-13.00 WIB, dan merupakan program bakat minat sehingga pelaksanaan latihan mengikuti jam pelajaran sekolah. Program PMR dirancang pada awal tahun anggaran sekolah, sehingga apabila ada kegiatan yang berasal dari luar sekolah yang bersifat insindental, pihak sekolah mengalami kesulitan pendanaan dan pada akhirnya belum tentu berpartisipasi. 
Kegiatan unggulan dalam PMR di SMA Katolik Frateran Malang adalah evaluasi kegiatan bakat minat yang diadakan disetiap akhir semester genap, tujuannya adalah mengasah dan menuangkan serta mengkolaborasikan semua kemampuan siswa-siswi yang mengikuti kegiatan bakat minat selama kegiatan pembelajaran berlangsung kedalam sebuah pentas drama sekolah. Hal ini diharapkan dapat menumbuhkan rasa kemanusiaan, kesamaan, kenetralan, dan kesatuan.

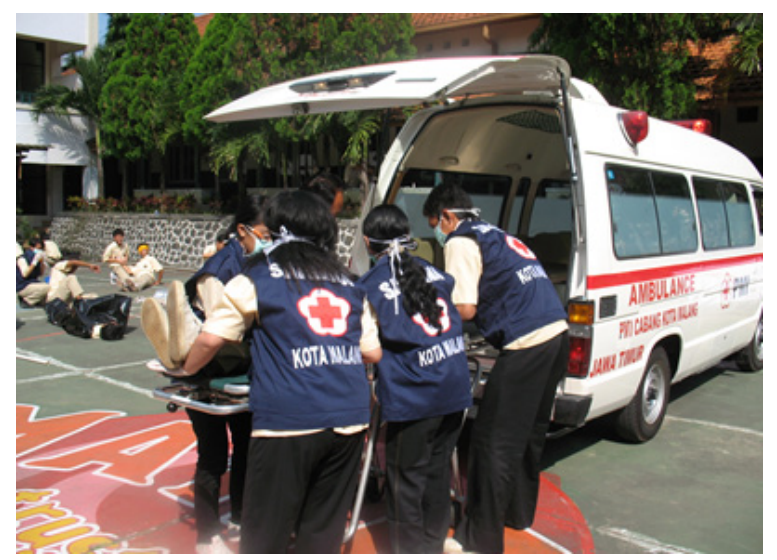

Gambar 3. Kegiatan evaluasi PMR di SMA Katolik Frateran

\section{SMK Negeri 2 Malang}

Kegiatan PMR di SMK Negeri 2 Malang atau disebut dengan ARSAMKANIDA (Arek SMK Negeri 2 Malang) dimulai awal tahun 2008. Tenaga pelatih kegiatan rutin bekerja sama dengan KSR-PMI unit UM. Pada tahun 2009 ini awal dari prestasi ARSAMKANIDA sebagai juara umum lomba PMR se-wilayah kecamatan Karang Ploso, Kabupaten Malang. Semua pelatih masih berstatus mahasiswa anggota KSR-PMI unit UM, sehingga tenaga silih berganti tetapi tetap dalam tanggung jawab KSR-PMI unit UM.

Kebijakan sekolah dalam penentuan jam belajar siswa siswa kelas X dan XI di siang hari, sehingga pelaksanaan PMR setiap hari selasa jam 08.00-11.00 WIB sehingga jam pagi hari di fokuskan untuk ekstrakurikuler, adapun sisw yang mengikuti PMR berjumlah 96 siswa terdiri dari 93 siswa perempuan dan sisanya laki-laki. Sebagian besar anggota ARSAMKANIDA adalah siswa dari jurusan keperawatan. Kegiatan PMR bersinergi dengan kegiatan UKS, sehingga materi pelatihannya menjadi agak berbeda dengan PMR pada umumnya. Materi pelatihannya meliputi PHBS, pengenalan narkotika, pengenalan Tanaman Obat Keluarga (TOGA), pertolongan pertama, perawatan keluarga, bongkar pasang tenda, siaga bencana, donor darah, dan kepemimpinan.

PMR di SMK Negeri 2 Malang merupakan contoh kegiatan Remaja Sebagai Agen Perubahan (Youth Agent and Behavior Chance). Kegiatan ini mendapat dukungan dari Palang Merah Denmark, karena itu dilatih langsung oleh PMI kota Malang.

Kegiatan latihan rutin Palang Merah Remaja di SMK Negeri 2 Malang selalu diawali dengan warming up (pemanasan) terlebih dahulu, hal ini dimaksudkan agar dalam melaksanakan kegiatan yang bersifat fisik anggota Palang Merah Remaja tidak mengalami cedera. Hal ini dapat memperkokoh rasa kebersamaan dalam setiap anggota dan salah satu wujud aplikasi nilai kesatuan.

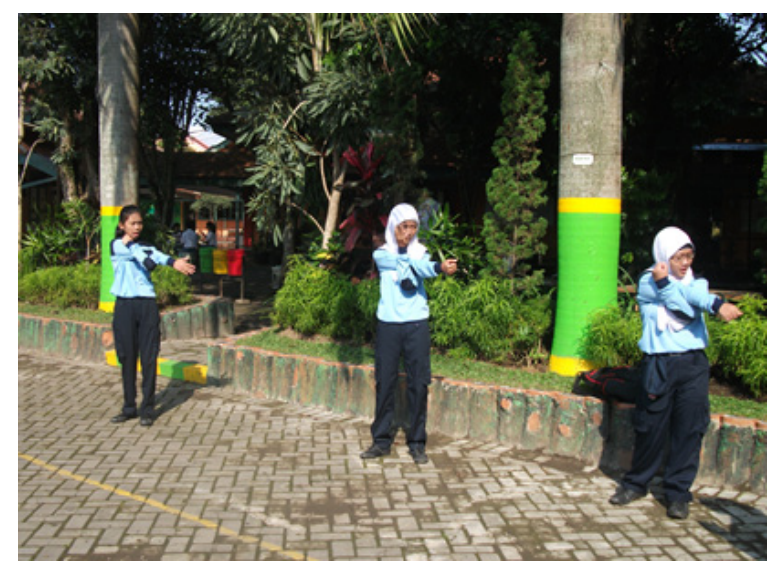

Gambar 4. Warming up sebelum kegiatan rutin

SMA Negeri 5 Malang

Aktivitas PMR SMA Negeri 5 Malang atau disebut dengan DYRC (Dhamysoga Youth Red Cross) ada sejak tahun 80an. Peran alumni PMR sangat dominan dalam hal dukungan ketenagaan, penyusunan program kerja, finansial, dan motivasi kepada adik kelas sebagai anggota PMR. Pelatih PMR berasal dari alumni yang sekarang menjadi tenaga tetap di PMI kota Malang.

Anggota PMR SMA Negeri 5 Malang diikuti oleh siswa kelas X dan XI berjumlah 42 terdiri dari 31 perempuan dan 11 laki-laki. Latihan rutin diadakan setiap hari Kamis jam 15.30-17.00 WIB dan Jumat jam 13.00-17.00 WIB. Dengan materi pertolongan pertama, perawatan keluarga, bongkar pasang tenda, siaga bencana, donor darah, dan kepemimpinan. Kegiatan donor darah 
dilaksanakan secara rutin setiap 3 bulan sekali, mengikuti berbagai macam lomba baik di tingkat kota dan propinsi. Untuk meneruskan kegiatan kepalangmerahan, alumni PMR SMA Negeri 5 Malang dalam kurun waktu 5 tahun terakhir menjadi anggota aktif KSR-PMI unit di universitas.

Kegiatan PMR di SMA Negeri 5 Malang sama dengan PMR SMK Negeri 2 Malang ditunjuk oleh PMI kota Malang menjadi salah satu dari tiga sekolah yang menjadi contoh kegiatan remaja sebagai agen perubahan yang didukung dan dilatih langsung oleh PMI kota Malang dengan dukungan pendanaan dari Palang Merah Denmark.

Kegiatan PMR SMA Negeri 5 Malang adalah dengan mengadakan latihan outbond training yang diadakan diluar sekolah, hal ini selain memberi kesempatan kepada para anggota untuk lebih dekat dan mengenal anggota yang lain, hal ini juga untuk mempererat rasa persaudaraan antar anggota, senior, maupun alumni serta rasa saling memiliki di dalam tubuh PMR SMA Negeri 5 Malang. Adapun keakraban yang terlihat pada setiap diri anggota PMR di SMA Negeri 5 malang.

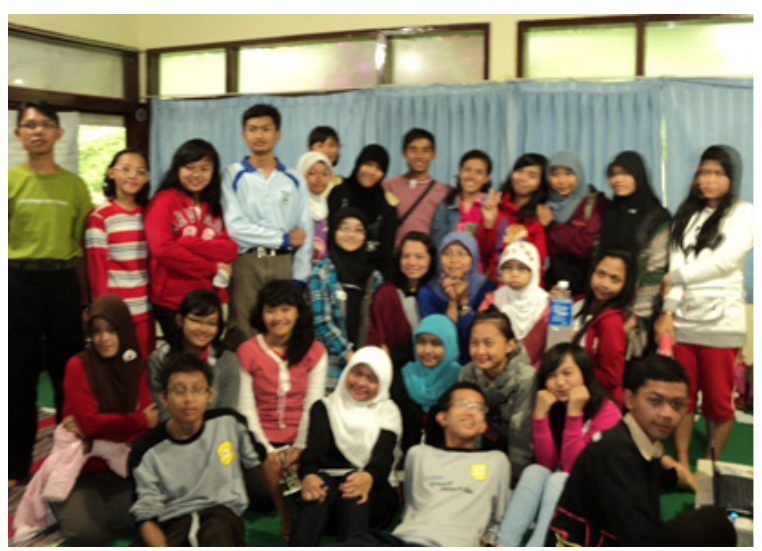

Gambar 5. Keakraban sesama anggota PMR di SMA Negeri 5 Malang

Implementasi nilai-nilai karakter dalam kegiatan PMR tingkat wira binaan PMI Kota Malang adalah sebagai berikut:

Nilai Kemanusiaan di MAN Malang I diimplementasikan dengan kegiatan bakti sosial yang bersifat insindental serta donor darah rutin yang dilakukan setiap 3 bulan sekali; di SMK Negeri 2 Malang lebih kepada setiap memperingati hari AIDS dengan membagi-bagikan stiker, serta mengajari bagaimana caranya agar menolong orang tidak takut; di SMA Negeri 5 Malang lebih kepada kegiatan yang bersifat kemasyarakatan, hal ini dirasa dapat menambah pengalaman baru bagi anggota PMR yang lain; dan di SMA Katolik Frateran diimplementasikan kepada anggota yang niat mengikuti kegiatan PMR, selain itu memberikan pertolongan kepada teman yang membutuhkan, baik saat didalam kelas, luar kelas, maupun pada saat kegiatan bakat minat berlangsung;

Nilai Kesamaan di MAN Malang I diimplementasikan dengan mempererat rasa kebersamaan, kegiatan latihan rutin, disaat anggota lain ada yang sakit, anggota yang lain juga ikut merasakan sakit; di SMK Negeri 2 Malang berusaha menerapkan jiwa corsa (kebersamaan) kepada setiap anggota seperti: memakai kostum yang sama saat latihan, kalau ada yang tidak seragam ya dihukum, apalagi kalau terlambat hukumannya lebih berat tapi kita masih mempertimbangkan humanisnya; di SMA Negeri 5 Malang menghilangkan senioritas dan junioritas hal ini di maksudkan agar teman-teman anggota bisa lebih dekat satu sama yang lain, tidak sungkan, tidak malu, biasanya kita adakan forum sharing antara semua angkatan PMR; dan di SMA Katolik Frateran lebih mengedepankan penyatuan semua unsur yang ada di sekolah tersebut dan lebih menonjolkan hubungan multikultural yang harmonis, tidak membeda-bedakan Suku, Agama, Ras dan Antar Golongan, masyarakat SMA Katolik Frateran malang sangat bersatu dalam keberagaman.

Nilai Kenetralan di MAN Malang I diimplementasikan dengan tidak membela organisasi manapun termasuk dalam kegiatan sehari-hari, baik pada saat latihan rutin maupun saat menjadi petugas kesehatan pada upacara bendera; di SMK Negeri 2 Malang rela menolong siapapun yang membutuhkan baik siswa, guru, maupun anggota ekstrakurikuler lain yang membutuhkan; SMA Negeri 5 Malang diimplementasikan dengan rela menolong siapapun tanpa membedakan golongan apapun, dan di SMA Katolik Frateran adalah dengan membebaskan anggotanya untuk mengikuti ekstrakurikuler selain PMR, seperti: pramuka, pencak silat, basket, dan lain sebagainya.

Nilai Kemandirian di MAN Malang I diimplmentasikan dengan penggunaan dana yang 
selama ini jarang sekali atau bahkan hampir dalam setiap kegiatan tidak mendapatkan bantuan dari pihak manapun kecuali sekolah yang selalu mendukung dari segi pendanaan, para anggota berinisiatif untuk mengumpulkan dana secara sukarela; SMA Negeri 5 Malang diimplementasikan kepada pengurusan administrasi secara mandiri dan pendanaan yang tidak bergantung terus-menerus kepada sekolah; di SMK Negeri 2 Malang diimplementasikan kepada penerapan kedisiplinan anggota PMR, baik disiplin waktu saat latihan rutin atau menjelang lomba maupun disiplin dalam berpakaian; dan di SMA Katolik Frateran lebih kepada mengumpulkan dana kas PMR yang digunakan untuk kegiatan sehari-hari.

Nilai Kesukarelaan di MAN Malang I diimplementasikan berupa pemberian pertolongan kepada orang lain tanpa meminta imbalan apapun; SMK Negeri 2 Malang dengan merangkul semua kegiatan ekstrakurikuler yang ada di sekolahtersebut untuk ikut memeriahkan pelaksanaan salah satu program kerja PMR; di SMA Negeri 5 Malang diimplementasikan dengan memberikan pertolongan tanpa imbalan apapun, terutama saat menjadi petugas kesehatan dalam upacara bendera; dan SMA Katolik Frateran juga diimplementasikan dengan memberikan pertolongan tanpa imbalan apapun, terutama saat menjadi petugas kesehatan dalam upacara bendera di harihari besar maupun upacara bendera rutin.

Nilai Kesatuan di MAN Malang I di implementasikan dengan mempererat hubungan silaturahmi dengan warga sekolah terutama yang ikut ekstrakurikuler lain; SMK Negeri 2 Malang juga diimplementasikan dengan menjalin hubungan silaturahmi dengan warga sekolah dan anggota ekstrakurikuler yang lain;di SMA Negeri 5 Malang mempererat hubungan senior dan junior, diharakan tidak ada kesenjangan diantara sesame anggota palang merah; dan SMA Katolik Frateran di implementasikan kepada penyatuan semua anggota PMR mulai kelas X hingga kelas IX;

Nilai Kesemestaan di MAN Malang I diimplementasikan berupa penyuluhan kesehatan kepada warga madrasah, di SMK Negeri 2 Malang diimplementasikan dengan kehadiran PMR di setiap kegiatan yang diselenggarakan oleh sekolah serta menawarkan bantuan kepada ekstrakurikuler lain yang membutuhkan pertolongan dari anggota PMR; SMA Katolik Frateran Malang lebih kepada kehadiran PMR di setiap kegiatan sekolah baik saat upacara bendera maupun kegiatan sekolah lainnya; dan di SMA Negeri 5 Malang diimplementasikan kepada pengiriman wakil anggota PMR untuk kegiatan nasional dan Internasional yang baru dilaksanakan di gorontalo dan Malaysia beberapa waktu yang lalu.

\section{Simpulan dan Saran}

\section{Simpulan}

Simpulan yang bisa diambil dalam penelitian tentang implementasi nilai-nilai karakter dalam kegiatan Palang Merah Remaja adalah:

Nilai Kemanusiaan di MAN Malang I lebih kepada kegiatan bakti sosial, di SMK Negeri 2 Malang memperingati hari AIDS dengan membagikan stiker, di SMA Negeri 5 Malang mengimplemntasikan kegiatan yang bersifat kemasyarakatan, dan di SMA Katolik Frateran pelaksanaannya lebih ditujukan kepada anggota yang niat mengikuti kegiatan PMR.

Nilai Kesamaan di keempat sekolah diimplementasikan dengan penerapan jiwa corsa.

Nilai Kenetralan di MAN Malang I tidak membela organisasi manapun, sedangkan di SMK Negeri 2 Malang dan SMA Negeri 5 Malang rela menolong siapapun tanpa membedakan SARA, sedangkan di SMA Katolik Frateran adalah dengan membebaskan anggotanya untuk mengikuti ekstrakurikuler selain PMR.

Nilai Kemandirian di MAN Malang I dan SMA Negeri 5 Malang diimplementasikan dengan pengurusan administrasi secara mandiri dan pendanaan yang tidak bergantung terus-menerus kepada sekolah, dan di SMK Negeri 2 Malang lebih penerapan kedisiplinan anggota PMR, sedangkan di SMA Katolik Frateran lebih kepada mengumpulkan dana kas PMR.

Nilai Kesukarelaan di MAN Malang I, SMAK Negeri 2 Malang, SMA Negeri 5 Malang, dan SMA Katolik Frateran serempak memberikan pertolongan tanpa imbalan apapun, terutama saat menjadi petugas kesehatan dalam upacara bendera.

Nilai Kesatuan di keempat sekolah diimplementasikan dengan mempererat hubungan silaturahmi dengan warga sekolah. 
Nilai Kesemestaan di MAN Malang I diimplementasikan dengan penyuluhan kesehatan, di SMK Negeri 2 Malang dan SMA Katolik Frateran Malang diimplementasikan dengan kehadiran PMR di setiap kegiatan sekolah, dan SMA Negeri 5 Malang diimplementasikan pengiriman duta PMR untuk kegiatan nasional dan Internasional.

Saran

Adapun saran yang bisa diambil dalam penelitian tentang implementasi nilai-nilai karakter dalam kegiatan Palang Merah Remaja adalah sebagai berikut:

Sekolah: Diharapkan sekolah mampu memfasilitasi semua kegiatan ekstrakurikuler utamanya Palang Merah Remaja; Diharapkan sekolah mampu bekerja sama dengan tim pelatih yang menjadi salah satu tolok ukur dalam keberhasilan mengimplementasikan nilai-nilai karakter utamanya dalam kegiatan kegiatan Palang Merah Remaja.

Palang Merah Indonesia: Diharapkan PMI selalu menjadi pembimbing dan motivator bagi pelatih maupun sekolah dalam mengimplementasikan nilai-nilai karakter, utamanya dalam kegiatan Palang Merah Remaja; Diharapkan PMI selalu mendukung program kerja Palang Merah Remaja tiap sekolah dengan memberikan fasilitas berupa pelatihan kepada anggota PMR maupun kepada pelatih PMR.

Peneliti selanjutnya: Diharapkan Penelitian tidak hanya dilakukan di PMR tingkat wira saja, akan tetapi penelitian juga dilakukan di tingkat madya dan mula; Diharapkan Penelitian tidak hanya dilakukan kepada PMR yang menjadi binaan PMI saja, akan tetapi juga dilakukan kepada PMR yang menjadi binaan KSR-PMI unit perguruan tinggi di kota Malang; Penelitian tidak hanya sampai pada pembentukan karakter saja, akan tetapi bisa dikembangkan lebih dalam lagi, misalnya: manajemen PMR, peran sekolah, dan lain sebagainya.

\section{Daftar Pustaka}

Hasibuan dan Mudjiono. (2002). Proses belajar mengajar. Bandung. PT Remaja Rosdakarya.

Komar, Oong. (2006). Filsafat pendidikan non formal. Bandung: CV Pustaka Setia.

Marzuki, Saleh. (2009). Dimensi-dimensi pendidikan nonformal. Malang: Rosindo.

Samsuri. (2012). Pendidikan karakter warga negara: kritik pembangunan karakter bangsa. Surakarta: Pustaka Hanif.

Sungkowo. (2010). Juknis penyusunan program pengembangan diri melalui kegiatan ekstrakurikuler di sma. Jakarta.

Umar Tirtarahardja dan La Sulo. (2005). Pengantar Pendidikan. Jakarta. PT Rineka Cipta

Usman, Husaini. (1998). Organisasi: teori, praktek, penelitian, dan kasus. CV Alfabeta: Bandung.

Usman, Ulla Nuchrawaty. (2007). Pendidikan remaja sebaya : Kesehatan dan kesejahteeraan remaja untuk pendidik sebaya. Markas Pusat PMI : Jakarta 